\title{
EVALUATION OF THE EFFECT OF IMPORTED FOREIGN BREEDS ON THE SPORTS PERFORMANCE OF WARM-BLOOD HORSES IN THE CZECH REPUBLIC
}

\author{
S. Makovská Krčová
}

Received: July 25, 2012

\begin{abstract}
MAKOVSKÁ KRČOVÁ, S.: Evaluation of the effect of imported foreign breeds on the sports performance of warmblood horses in the Czech Republic. Acta univ. agric. et silvic. Mendel. Brun., 2012, LX, No. 6, pp. 243-250

The objective of the study was to evaluate the effect of foreign studbooks in the breeding of warmblood horses in the Czech Republic in the period 2000-2009. We included the following effects in our research: group based on the prevailing horse breed, year of start, sex, age and country of birth. We evaluated the effect of these parameters on the sports performance in show jumping competitions. The sports performance was based on the number of PPB points. The data were processed statistically using the general linear model (GLM). We discovered that the effect of these parameters was statistically highly significant. The HOLST1 group showed the highest performance (4.754 PPB points) and stands for individuals with a 100\% proportion of the Holstein studbook. The second most successful group was KWPN1 (4.748). In the individual years of our investigations we found 22 statistically significant differences. For the entire period the number of PPB points was the highest in 2009 (3.420) and the lowest in 2000 and 2001 (2.678 and 2.779, respectively). The performance tended to increase in the individual years. We compared the performance of horses born in the Czech Republic and abroad and we discovered that performance was statistically higher in the group of imported horses. In terms of the effect of sex on the performance of horses in show jumping events the group of stallions showed the highest performance based on PPB points (3.842). In the experiment we estimated the effect of age on the sports performance; the group of 9-year-old horses achieved the highest performance based on PPB points (3.433).
\end{abstract}

horses, Czech warm-blood horses, sport performance

At present 5 warm-blood sports breeds are registered in the Czech Republic. The prevailing breed is the Czech warm-blood (CT) followed by the Slovakian warm-blood bred in the Czech Republic (CS), Moravian warm-blood (MT) and the Kinsky horse (KK). In the past cca 30 years of breeding these horses we have seen a qualitative change from the universal utility type to the sports type (MARŠÁLEK, 2011). Particularly the CT and CS are intensively bred for sports jumping performance using the imported foreign breeds bred for sports performance (JISKROVÁ, 1996, 2004) for intensive improvement. At the present time the populations of CT and CS have the same genetic base as other European populations of horses bred for jumping performance. The reason for giving preference to sires imported predominantly from Germany, Holland and France is to concentrate the gene pool of the most important world bloodlines and mare lines (MISAŘ and JISKROVÁ, 2005).

THORÉN HELLSTEN et al. (2009) dealt with the infusion of imported breeds and their effect on the improvement of the Swedish warm-blood. In their study they evaluated the effect of foreign stallions in the breeding of the Swedish warm-blood and its genetic evaluation. In their study DUBOIS and RICARD (2007) monitored the effect of foreign sports breeds of horses on the performance of the Selle Français breed. 
POSTA et al. (2009) touched on the global demand for sports horses oriented at show jumping and dressage. According to the authors the population of the Hungarian sports horse has the same genetic base as other European populations of horses used exclusively in show jumping events.

Besides the irreplaceable role of reliable lines and breeds used in the breeding of warm-blood horses, the English Thoroughbred plays an important role. According to JISKROVÁ (2011) the main function of the English Thoroughbred in breeding is an infusion of blood with the purpose of boosting the constitution toughness and sports qualities.

In the Czech Republic the monitoring of the sports performance was launched as early as 1983 (PELLAROVÁ, 1986). According to methods by PELLAROVÁ (1986) evaluation of the show jumping performance is based on average auxiliary points (PPB) for one start; every year a ranking list of the success rate of sports horses is compiled. Since 1985 these data have been published on a yearly basis in surveys of sports horses in the Czech Republic for the respective riding season and provide all information about the performance of sports horses, incl. some results of progeny testing of sires (PELLAROVÁ and DUŠEK, 1990).

In the present study we evaluated the effect of foreign imported breeds bred for sports performance on the sports performance of the population of sports horses in the Czech Republic.

\section{MATERIAL AND METHODS}

The basic database was created manually by entering the jumping sports performance of horses in the Czech Republic for the period of 2000-2009. The sports performance was characterised by the number of PPB points. A total of 24612 PPB points was collected. We singled out results of classical show jumping events, i.e. from the level of grade $\mathrm{Z}$ (height $100 \mathrm{~cm}$ ) to the level of grade $\mathrm{T}^{* *}$ (height $150 \mathrm{~cm}$ )

For each horse we entered into the database the effect of sex, year of start, year of birth, age at start, place of birth of horse (Czech or imported), group based on the prevailing studbook in the pedigree (thereinafter only group) and characteristics of performance based on PPB points.

Auxiliary data used to place the horse into a group were the following: name of horse, sire, dam and sire of the dam. Horses born in the Czech Republic were placed into individual groups according to the prevailing studbook in the pedigree. In terms of horses born on the territory of another country we respected the studbook in which they were registered. Tab. I gives the resulting sectioning of the database.

The horses were divided into ten groups based on their age.

Data were statistically processed using the general linear model (GLM) in the statistical programme
SAS, version 9.1 according to the following model equation:

$$
\mathrm{y}_{\mathrm{ijklmn}}=\mu+\mathrm{p}_{\mathrm{i}}+\mathrm{q}_{\mathrm{j}}+\mathrm{r}_{\mathrm{k}}+\mathrm{s}_{\mathrm{j}}+\mathrm{v}_{\mathrm{m}}+\mathrm{e}_{\mathrm{ijklmn}},
$$

where:

$\mathrm{y}_{\mathrm{ijklmn}}$...studied effect

$\mu$...........total average of the group

$\mathrm{p}_{\mathrm{i}}$..........fixed effect of the $\mathrm{i}^{\text {th }}$ breeding group $(i=1, \ldots$, 73)

$q_{i}$.........fixed effect of the $j^{\text {th }}$ place of birth of the horse $(j=1.2)$

$r_{k}$.........fixed effect of the $k^{\text {th }}$ year of start $(k=1, \ldots, 10)$

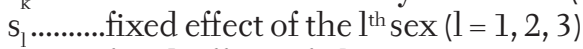

$\mathrm{v}_{\mathrm{m}}$........fixed effect of the $\mathrm{m}^{\text {th }}$ age category $(\mathrm{m}=\mathrm{l}$, ...10)

$\mathrm{e}_{\mathrm{ijklmn}}$....random effect.

In cases when the effect was statistically significant we subsequently subjected the data to Scheffe's method of multiple comparison.

\section{RESULTS AND DISCUSSION}

Tab. II gives the results of the GLM model. All the effects showed that they had a statistically highly significant effect on the sports performance of horses.

Tabs. III and IV show results of the multiple comparison effect of the group. Tab. III gives the 10 most successful groups starting in show jumping events. Tab. IV presents results of groups where the number of horses was $\mathrm{n} \geq 100$.

The performance of horses of the groups in Tab. III was seen as high and suggests breeding for jumping performance. The group showing the highest performance was the HOLSTl group (4.754 PPB points) which includes horses with a $100 \%$ proportion of the Holstein studbook in the pedigree. This is a positive proof of how popular these high-performance horses registered in the Holstein studbook are with Czech riders and breeders. Czech breeders prefer Holstein horses as improvers, particularly for the CT and CS breeds. Despite the noticeably lower number of PPB points and lower number of horses the second most successful group was KWPN1 (4.748). The results of the WBFSH confirmed the considerable jumping abilities of the Studbook of the Royal Dutch Sport Horse (KWPN); according to WBFSH this studbook has held a primacy every year since the beginning of 2004 until the present. The AUTWB4 group offers an interesting insight; as the only group out of the 10 most successful groups it presented horses born in the Czech Republic which have a 50\% proportion of a foreign studbook in their pedigree, in this case the studbook of the Austrian warm-blood horse. A total of 22 horses (89 PPB points) reached an average 4.518 PPB points.

Tab. IV gives the order of the groups based on the number of individuals in the researched period. Although the numbers of horses in the groups differ, the most numerous were groups with a proportion 


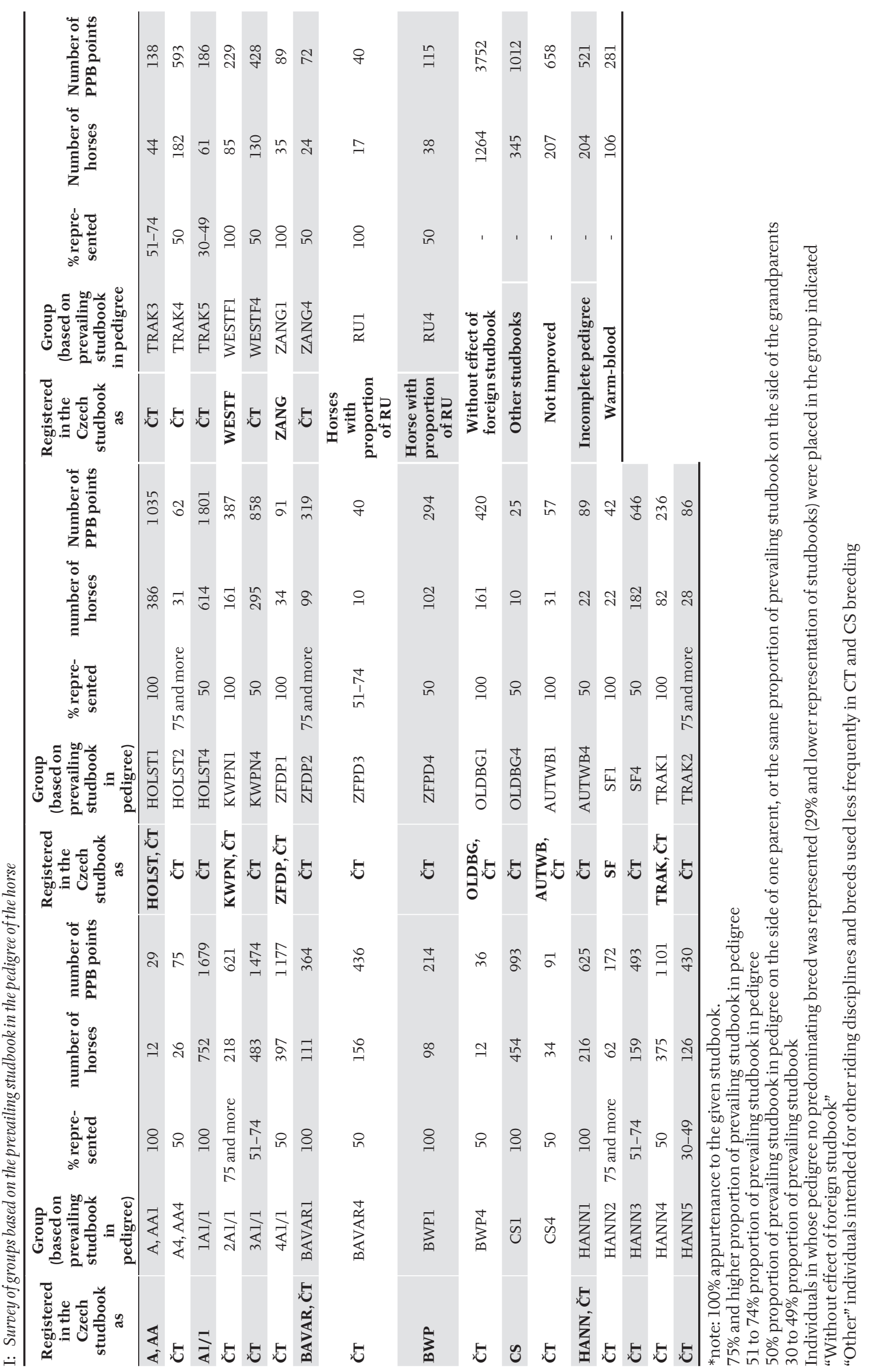


II: Results of analysis of variance - general linear model, significance of the effect of monitored factors

\begin{tabular}{lccccc}
\hline $\begin{array}{c}\text { Source of } \\
\text { variability }\end{array}$ & Sum of squares & $\begin{array}{c}\text { Degree of } \\
\text { freedom }\end{array}$ & Average square & F value & $\begin{array}{c}\text { Level of } \\
\text { significance }\end{array}$ \\
\hline Group & 3918.705 & 47 & 83.377 & 19.906 & $<0.0001$ \\
Cz/Imp. & 367.924 & 1 & 367.924 & 87.841 & $<0.0001$ \\
Year of start & 299.110 & 9 & 33.234 & 7.935 & $<0.0001$ \\
Sex & 1079.487 & 2 & 539.744 & 128.863 & $<0.0001$ \\
Age category & 2291.985 & 9 & 254.665 & 60.801 & $<0.0001$ \\
\hline
\end{tabular}

III: The 10 most successful groups based on the average PPB points

\begin{tabular}{lcccc}
\hline \multicolumn{1}{c}{ Group } & \% represented & No. of horses & $\begin{array}{c}\text { No. of PPB } \\
\text { points }\end{array}$ & Average PPB \\
\hline Holstein warm-blood (HOLST1) & 100 & 386 & 1035 & 4.754 \\
\hline Studbook of Royal Dutch Sports Horse (KWPN1) & 100 & 161 & 387 & 4.748 \\
Hanoverian warm-blood (HANN1) & 100 & 216 & 625 & 4.733 \\
Zangerscheide (ZANG1) & 100 & 35 & 89 & 4.604 \\
Austrian warm-blood (AUTWB4) & 50 & 22 & 89 & 4.518 \\
\hline Oldenburg warm-blood (OLDBG1) & 100 & 161 & 420 & 4.371 \\
Bavarian warm-blood (BAVAR1) & 100 & 111 & 364 & 4.282 \\
Belgian warm-blood (BWP1) & 100 & 98 & 214 & 4.093 \\
Westphalia warm-blood (WESTF1) & 100 & 85 & 229 & 4.036 \\
\hline Selle français (SF1) & 100 & 22 & 42 & 3.970 \\
\hline
\end{tabular}

IV: Survey of groups with $n \geq 100$ numbers of horses

\begin{tabular}{lccccc}
\hline \multicolumn{1}{c}{ Group } & $\begin{array}{c}\text { \% } \\
\text { represented }\end{array}$ & $\begin{array}{c}\text { No. of } \\
\text { horses }\end{array}$ & $\begin{array}{c}\text { N o. of PPB } \\
\text { points }\end{array}$ & $\begin{array}{c}\text { Average of } \\
\text { PPB points }\end{array}$ & \% \\
\hline No effect t of foreign studbook & - & 1264 & 3752 & 2.692 & 14.52 \\
English Thoroughbred (A1/1) & 100 & 752 & 1679 & 2.322 & 8.64 \\
Holstein warm-blood (HOLST4) & 50 & 614 & 1801 & 3.173 & 7.06 \\
\hline English Thoroughbred (3A1/1) & $51-74$ & 483 & 1474 & 2.986 & 5.55 \\
\hline Slovakian warm-blood (CS1) & 100 & 454 & 993 & 3.437 & 5.22 \\
\hline English Thoroughbred (4A1/1) & 50 & 397 & 1177 & 2.954 & 4.56 \\
Holstein warm-blood (HOLST1) & 100 & 386 & 1035 & 4.754 & 4.44 \\
\hline Hanoverian warm-blood (HANN4) & 50 & 375 & 1101 & 2.959 & 4.31 \\
\hline Studbook of Royal Dutch Sports Horse (KWPN4) & 50 & 295 & 858 & 3.120 & 3.39 \\
\hline Hanoverian warm-blood (HANN1) & 100 & 216 & 625 & 4.733 & 2.48 \\
\hline Selle français (SF4) & 50 & 182 & 646 & 3.970 & 2.09 \\
\hline Trakehner horse (TRAK4) & 50 & 182 & 593 & 3.049 & 2.09 \\
\hline Oldenburg warm-blood (OLDBG1) & 100 & 161 & 420 & 4.371 & 1.85 \\
\hline Studbook of Royal Dutch Sports Horse (KWPN1) & 100 & 161 & 387 & 4.748 & 1.85 \\
\hline Hanoverian warm-blood (HANN3) & $51-74$ & 159 & 493 & 3.040 & 1.83 \\
\hline Bavarian warm-blood (BAVAR4) & 50 & 156 & 436 & 2.997 & 1.79 \\
\hline Westphalia warm-blood (WESTF4) & 50 & 130 & 428 & 3.042 & 1.49 \\
\hline Hanoverian warm-blood (HANN5) & $30-49$ & 126 & 430 & 2.915 & 1.45 \\
\hline Bavarian warm-blood (BAVAR1) & 100 & 111 & 364 & 4.282 & 1.28 \\
\hline
\end{tabular}

of blood of the English Thoroughbred in the pedigrees of the horse population. The key criterion of performance of the English Thoroughbred is maximal speed in canter in flat races. If such a tested individual fails either in terms of performance or from the physical point of view, it leaves the racecourse to be used for sports or recreational purposes. These eliminated individuals may be one of the possible reasons for the over-abundance of the English Thoroughbred in jumping sports, because their purchase cost is low. 


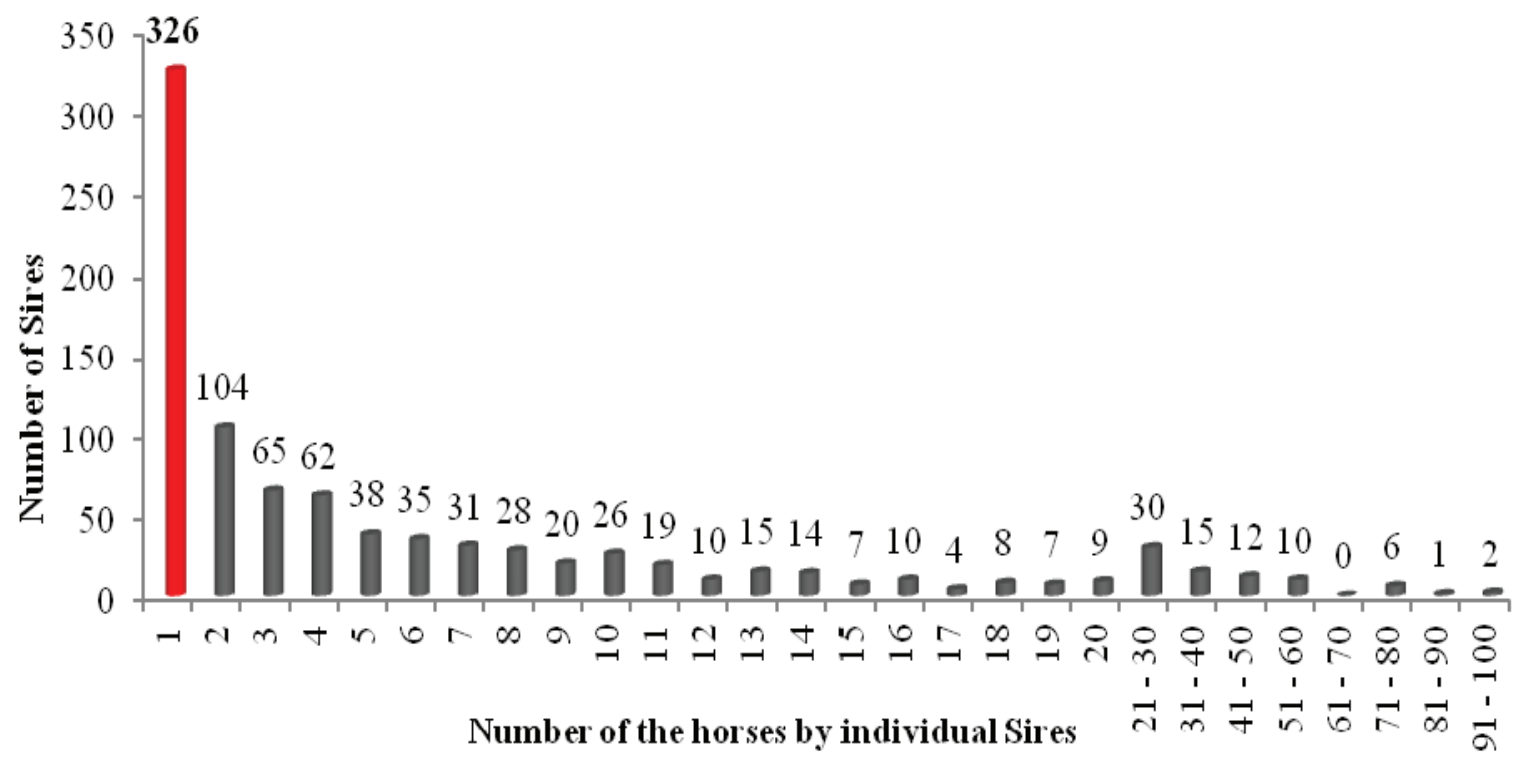

1: Number of horses born in the Czech Republic by individual sires

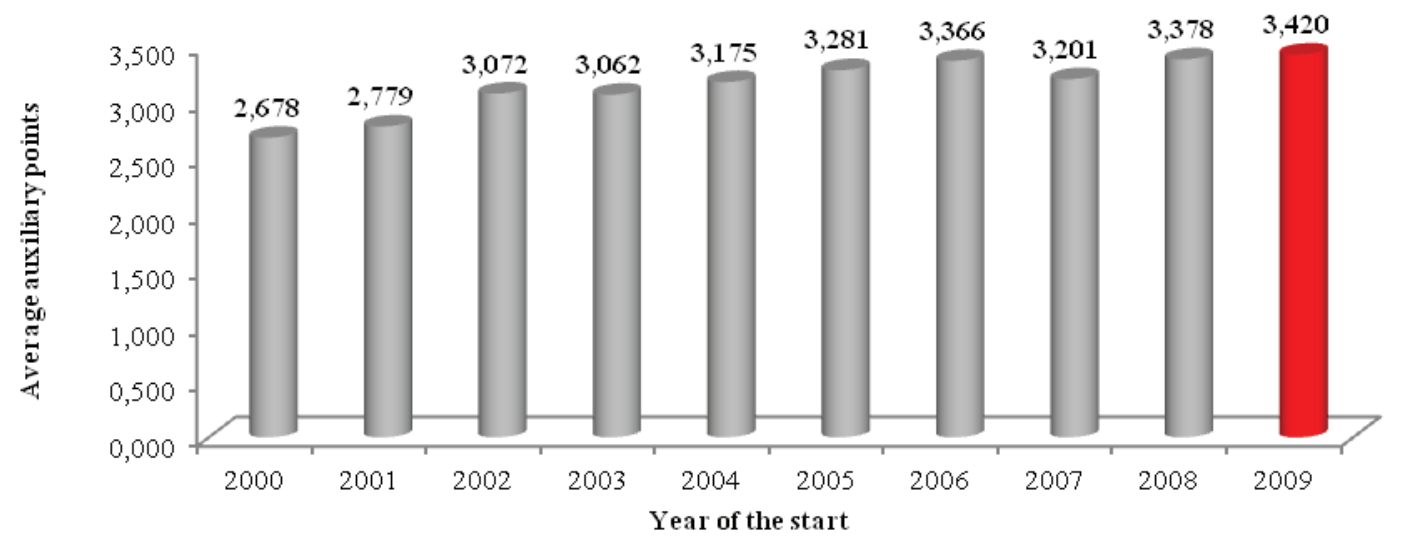

2: Average PPB points in individual years

- Number of the starts in thousands $\longrightarrow$ Average auxiliary points

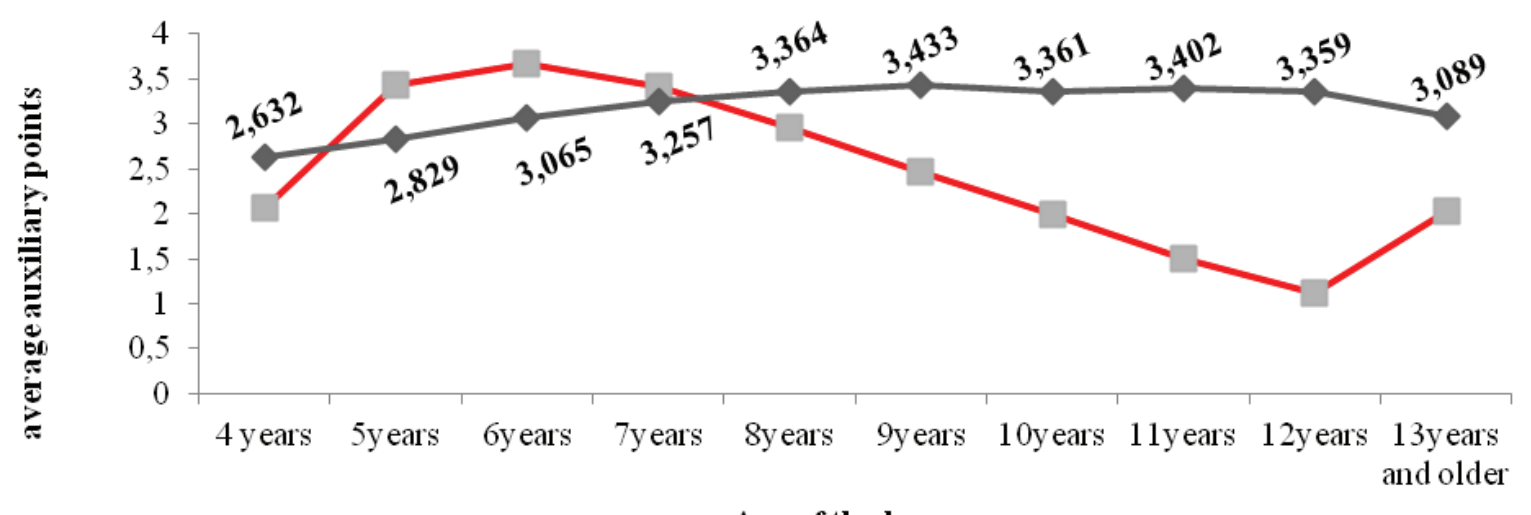

Age of the horses

3: Survey of the number of starts and average number of $\mathrm{PPB}$ points in the respective age categories 
The group without any prevailing studbook in the pedigree achieved the highest number of PPB points (3752). This group counted 1264 horses. They were individuals with an over-abundance of various studbooks in their pedigrees. Their average PPB points (2.692) were below the average PPB points (3.155) of the entire researched horse population.

The third most numerous group based on APP points (1801) were horses with a $50 \%$ proportion of prevailing Holstein studbook (HOLST4). The results of our observations clearly confirm that horses of the Holstein studbook are winning recognition in the breeding of warm-blood horses in the Czech Republic and that they carry the jumping properties. On the basis of detailed monitoring of pedigrees of the highest performing horses born in the Czech Republic with a considerable proportion of the Holstein studbook in their pedigree we concluded that in most cases the improver of jumping properties was the sire of the tested jumping line in the studbook of the Holstein breed and that the studbook of the Hanoverian warm-blooded, the Trakehner horse and the original AustrianHungarian half-bred foundation stock appeared in the pedigree of the dam. In these horse pedigrees the English Thoroughbred was a corrector of properties in $12.5 \%$ and $18.8 \%$, respectively.

Horses of the Slovakian warm-blood (CS) studbook achieved 993 PPB points, the average being 3.437. In total 454 horses were by 94 sires which gives 4.83 descendants per one sire. For that matter the small number of descendants per one sire has been a problem of Czech sports horse breeding for a long time. Graph 1 shows the number of descendants born in the Czech Republic by individual sires. In the entire population 326 stallions had only one descendant and represented $35.67 \%$ of all sires of sports horses in our population. The high number of sires with only one descendant starting in show jumping events indicates that the system of Czech horse breeders is inconsistent. Thanks to the opening of borders and modern reproduction technologies there is an inexhaustible supply of prime sires all over the world and breeders are ever more concentrating on a selection of foreign stallions or production of their progeny. It is true that the number of descendants is increasing, but in such a low number of descendants by one sire that genetic evaluation and estimation of breeding values cannot be carried out. So the sports breeds on the Czech Republic are a very inhomogeneous population.

In terms of evaluating the effect of the year of start, country of birth, sex and age on the performance of horses starting in show jumping events we found 22 statistically significant differences in the respective years of research. The highest PPB points (3.420) over the entire period were achieved in 2009. The PPB points (2.678) were the lowest in 2000 and 2001 (2.779). Graph 2 shows the increasing trend in performance in the respective years.

Another factor which affected the performance of the horses was the country of birth, or comparisons of the performance between horses born in the Czech Republic and abroad. The number of horses in the group of horses born in the Czech Republic was higher (19999 horses). The group of imported horses counted 4613 individuals. The performance of the imported horses was higher; the PPB points averaged 4.267, while the group of horses born in the Czech Republic achieved 2.899 PPB points. The results of following trials confirmed a significant difference between the two groups.

In terms of the effect of sex on the performance of horses in show jumping events we discovered that the highest performance in PPB points (3.842) was achieved by the group of stallions and the following trials showed a statistically significant difference between the group of stallions and group of geldings and between the group of stallions and group of mares. The highest number of PPB points was achieved by mares (47.30\%), followed by geldings (39.25\%) and stallions (13.45\%).

The last parameter was the effect of age on sports performance. The highest representation was that of six-year-old horses (14.92\%); on the other hand the lowest number of PPB points (4.51\%) was achieved by the group of 12-year-old horses. The highest performance based on PPB points (3.433) was achieved by the group of 9-year-old horses. A positive result is seen when we compare the two curves expressing the PPB points and number of starts in the respective age groups (Graph 3). At first both curves show an increasing trend but beginning from the 7-year-old age group of horses the numbers of starting horses in the individual categories differ. The number of starts gradually decreases and the PPB points remain balanced. Gradual growth and maintaining the PPB points indicate that the performance of horses and starts in competitions of a higher level of difficulty are increasing. In contrast, the decreasing number of starts of older horses in show jumping events could be due to health problems caused by overexertion of the organism in the higher levels of difficulty of show jumping events or the increasing demand for older horses suitable for pleasure riding.

\section{SUMMARY}

The objective of the study was to evaluate the effect of foreign studbooks in the breeding of warmblood breeds in the Czech Republic. In the 10-year period of 2000-2009 our focus was on warmblood breeds, or on studbooks of warm-blood breeds of horses bred for jumping performance. The horse population was divided into 48 groups based on the prevailing breed of horse and studbooks in 
a five-generation pedigree. The performance of these groups was evaluated according to the system of auxiliary points PPB. We took into account the following effects: group based on the prevailing share of horse breeds, year of start, sex, age and country of birth on sports performance in show jumping events. The data were processed statistically using the general linear model (GLM).

We discovered that the effect of these factors was statistically highly significant. The performance of the HOLST1 was the highest (PPB 4.754); this group includes horses with a 100\% proportion of the Holstein studbook in the pedigree. Second was the KWPN1 group (4.748).

The group without a prevailing studbook in the pedigree achieved the highest number of PPB points (3752). This group was represented by 1264 horses, individuals whose pedigrees had too many various studbooks. Their average PPB points (2.692) ranged below the average PPB points of the entire researched horse population (3.155). Numerous were also groups with the studbook of the English Thoroughbred in their pedigrees.

Horses with a 50\% proportion of prevailing Holstein studbook (HOLST4) was the third most numerous group based on the PPB points (1801). Our results confirmed that horses of the Holstein studbook are winning marked recognition in the breeding of warm-blood horses in the Czech Republic and that in this country they are the bearers of jumping properties.

Horses of the Slovakian warm-blood studbook (CS) achieved 993 PPB points, on average 3.437. A total of 454 horses were by 94 sires and corresponded to 4.83 descendants per one sire.

Of the entire researched group 326 stallions had only one descendant which is $35.67 \%$ of all sires of sports horses in our researched population. The high number of sires with only one descendant starting in show jumping events indicates that the system of breeding horses in the Czech Republic is inconsistent. The Czech sports breeds are an inhomogeneous population.

When evaluating the effect of the year of start, country of birth, sex and age on the performance of horses starting in show jumping events, we found 22 statistically significant differences among the individual years. The highest number of PPB points (3.420) for the entire period was achieved in 2009. The number of PPB points was the lowest in 2000 and 2001 (2.678 and 2.779, respectively). Graph 2 shows the increasing trend in performance in the individual years.

Another factor which affected the performance of horses was the country of birth, or comparisons of the performance of horses born in the Czech Republic and abroad. The group of horses born in the Czech Republic was larger (19999 horses). The group of imported horses consisted of 4613 horses. The performance of imported horses was higher and they achieved 4.267 PPB points on average, while the group of horses born in the Czech Republic achieved 2.899 PPB points. Results of following trials confirmed the significant difference between the two groups.

In terms of the effect of sex on the performance of horses in show jumping events we discovered that the highest number of PPB points (3.842) was achieved by the group of stallions; following trials showed a statistically significant difference between the group of stallions and group of geldings and between the group of stallions and group of mares. In per cent mares achieved the highest number of PPB points (47.30\%), followed by geldings (39.25\%) and stallions (13.45\%).

The last monitored factor was the effect of age on sports performance. The highest number of PPB points was seen in 6-year-old horses (in 14.92\%), in contrast to 12-year-old horses which had the lowest number of PPB points (4.51\%). The performance of 9-year-old horses based on the number of PPB points (3.433) was the highest.

\section{REFERENCES}

DUBOIS, C., RICARD, A., 2007: Efficiency of past selection of the French Sport Horse: Selle Français breed and suggestions for the future. Science Direct, Vol. 112, p. 161-171.

JISKROVÁ, I., 1996: Vliv importu zahraničních plemen na zvýšení sportovní výkonnosti českého teplokrevníka. (Doktorská disertační práce). Brno, 103 s. Mendelova zemědělská a lesnická univerzita $\mathrm{v}$ Brně.

JISKROVÁ, I., 2004: Hodnocení sportovní výkonnosti koní v České republice a odhad plemenné hodnoty českého teplokrevníka. (Habilitační práce). Brno, 100 s. Mendelova zemědělská a lesnická univerzita v Brně.

JISKROVÁ, I., 2011: The effect of the English Thoroughbred on the sport performance of horses in the Czech republic. Acta Universitatis Agriculturae et Silviculturae Mendelianae Brunensis, sv. 59, s. 175-181. ISSN 1211-8516.

MARŠÁLEK, M., 2011: Plemenitba v chovu koní [cit. 2011-13-06]. Dostupné na: http://www.cshipo.cz/ c-12-plemenarstvi.html.

MISAŘ, D., JISKROVÁ, I., 2005: Chov a šlechtění koní. Mendelova zemědělská a lesnická univerzita v Brně, 170 s.

PELLAROVÁ, A., 1986: Hodnocení plemenných hřebců podle sportovní výkonnosti jejich potomstev. Dílčí zpráva výzkumného úkolu, VSCHK Slatiňany, $5 \mathrm{~s}$.

PELLAROVÁ, A., DUŠEK, J., 1990: Odhad dědivosti výkonnosti sportovních koní. Bulletin VSCHK Slatiňany, č. 59, s. 1-15. 
PELLAROVÁ, A., DYKOVÁ, Z., TEPLÝ, V., MORAVEC, S., 2000-2009:Přehledy o sportovních koních ČR, VSCHK, Slatiňany.

POSTA, J., KOMLÓSI, I., MIHÓK, S., 2009: Breeding value estimation in the Hungarian Sport Horse population. The Veterinary Journal, Vol. 181, p. 1923.
THORÉN HELLSTEN, E., NÄSHOLM, A., JORJANI, H., STRANDBERG, E., PHILIPSSON, J., 2009: Influence of foreign stallions on the Swedish Warmblood breed and its genetic evaluation. Science Direct, Vol. 121, p. 207-214.

Address

Ing. Sylvie Makovská Krčová, Ústav chovu a šlechtění zvířat, Mendelova univerzita v Brně, Zemědělská 1 , 61300 Brno, Česká republika, e-mail:jiskrova@mendelu.cz 